\title{
ANATOMICALLY BASED 3D GEOMETRIC MODELING OF SPECIFIC BIOLOGICAL STRUCTURES
}

TIHAČEK ŠOJIĆ LJILJANA, MILIĆ ALEKSANDRA, ŽIVKOVIĆ R and ILIĆ J

School of Dentistry, University of Belgrade

(Received 13. December 2006)

Mechanical behavior of biological structures is a common subject of scientific research. The results of such investigations offer the precise insight into the biomechanical properties of biological structures and are usefull for predicting their behavior when subjected to loading. Although, such biomechanical investigations were conducted on experimental animals nowadays are very popular investigations concerning mathematical experimental models. The most common is the finite element method analysis. A digital model of a structure of interest has to be created for an investigation with the finite element method. Once the digital model is created with the use of computer technology numerous changes of elements and structures are possible, with different applications of the simulated load. The aim of this paper was to to present the development of our own threedimensional tooth model created for finite element analyses of intact tooth behavior under functional loading. Also, the idea was to evaluate the possibility for using finite element analysis in veterinary biomechanical research.

Our own 3D model was created using computer software according to available literature data, and facts gained from freshly exctracted intact teeth and plaster models. It is necessary to emphasize that FEM is an effective tool that has been adapted from the engineering arena to biomechanic research and has the potential to contribute to the growing scientific basis of knowledge in veterinary dentistry.

Kew words: finite element method, three-dimensional model

\section{INTRODUCTION}

Mechanical behavior of biological structures is a common subject of scientific research. The results of such investigations offer the precise insight into the biomechanical properties of biological structures and are usefull for predicting their behavior when subjected to loading. A great number of dental scientific investigations concerning tooth and bone biomechanical characteristics involved experiments on experimental animals, especially dogs. Results from such investigations were useful and contributed to better understanding of complex 
teeth, bone and surrounding soft tissues behavior. In spite of the differences between humans and experimental animals, both mammals must be accepted when biomechanical investigations are concerned. Increased public awareness of animal welfare issues and the fact that these experimental methods tend to be invasive, impractical and time-consuming led to the development of a simple, effective and noninvasive way of assessing the behavior of biological structures under loading. One of such methods is finite element method analyses.

Although known for decades, finite element method (FEM) gained popularity among researchers with computer science improvement. For any FEM analyses to be performed a computer model of structure under investigation has to be created. Lin et al., (2001) cited that FEM analysis could predict detailed mechanical responses of structures and alter the parameters in a more controllable manner, and therefore have become a popular analytical tool in dental biomechanical studies. In contrast to other methods involved in dental studies, once when a mathematical model is made, it is possible using the computer to simulate different stress applications and also change the shape and design of structures in numerous ways in order to gain more scientific data.

Evaluation of published literature showed that researchers have used twodimensional (2D) models in their studies (Anusavice and Hojjatie, 1987; Anusavice and Hojjatie, 1988; Zhou et al., 1989; Rees, 2002; Tanaka et al., 2003). Korioth and Versluis (1997) claim that depending on investigated structure and boundary conditions, $2 \mathrm{D}$ modeling may be justified as reasonable, especially when simplicity and efficiency are concerned. Other authors have used threedimensional (3D) models in their investigations (Lin et al., 2001; Ausiello et al., 2002).

The aim of this paper was to to present the development of our own threedimensional tooth model created for finite element analyses of intact tooth behavior under functional loading. Also, the idea was to evaluate the possibility for using finite element analysis in veterinary biomechanical research.

\section{MATERIAL AND METHODS}

The problem of biomechanical behavior of a complex structure with irregular geometry such is the tooth can be analyzed using the FEM. In order to perform the FE study one is obliged to create a digital model of the structure under investigation. The model presented in this paper was the 3D of an intact tooth. Morphological characteristics of an upper second premolar adopted from literature (Ash and Nelson, 2003) were used for creating the model external shape outlines. Definition and dimensions of internal tooth tissue layers (enamel, dentin, pulp chamber) were done according to data from Schilinburg et al. (1991). Using the mentioned morphologic details and dimensions, series of planes at different levels were defined with the outlines of the tooth cross-section at each level (Figure 1). 
The PRO-ENGINEER and SOLID WORK softwares were employed for these procedures. The next step was to describe the relations between planes. Afterwards the solid model was constructed by connecting these contours. The dentin parts of the tooth structure crown and root portions were modeled separately from the enamel shell. Later the enamel and dentin were assembled into the final model of the intact tooth (Figure 2).

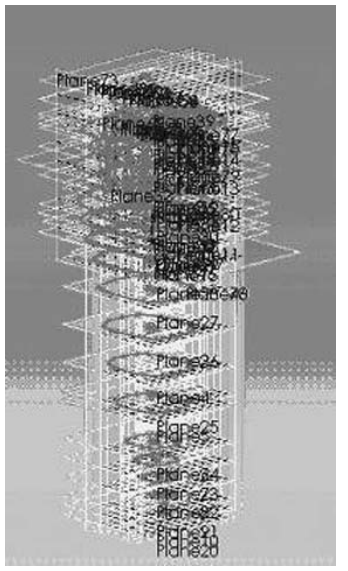

Figure 1. Defined series of planes at different levels with the outlines of the tooth cross-section at each level

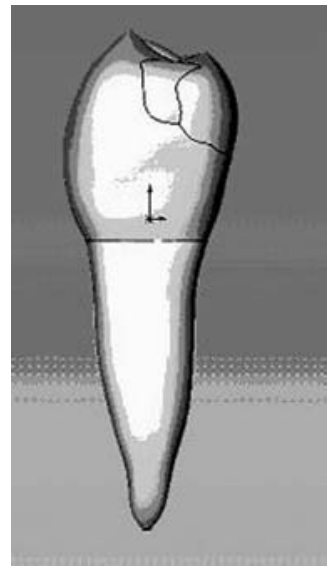

Figure 2. Enamel and dentin assembled into the final model of an intact tooth

All materials were considered isotropic and homogenous and were assigned adequate physical properties values according to literature data (Table 1). The dental pulp was modeled as a void, because pulp accepts very little of the load. (Rubin et al. 1983) Also the cement was not included in the model, due to its small dimensions and similar biomechanical characteristics as dentin.

Table 1. Physical values for the materials used in this study, Biomaterials properties database, (1996)

\begin{tabular}{|c|c|c|}
\hline & $\begin{array}{c}\text { Elastic modulus } \\
\text { Young's modulus }\end{array}$ & Poisson's ratio \\
\hline \hline Enamel & $84.1 \mathrm{GPa}$ & 0.33 \\
\hline Dentin & $14.7 \mathrm{GPa}$ & 0.31 \\
\hline
\end{tabular}

The model was constrained $2 \mathrm{~mm}$ apical from the cemento-enamel junction, representing the normal level of the alveolar crest and in that way boundary conditions in this stress and strain analysis were defined. Therefore the influence 
of the periodontal ligament (PDL) was not involved in the study. The final 3D model with defined boundary conditions is presented in Figure 3.

Creating the finite element mesh (pre-processing) for the described models was performed in NASTRAN software, where all later procedures (processing and post-processing) were planned to be finished. Intact tooth model mesh consisted of 15092 finite elements with 23300 nodes, as seen in Figure 4. The model was meshed with structurally solid elements defined by 10 nodes and having three degrees of freedom in tetrehedral bodies.

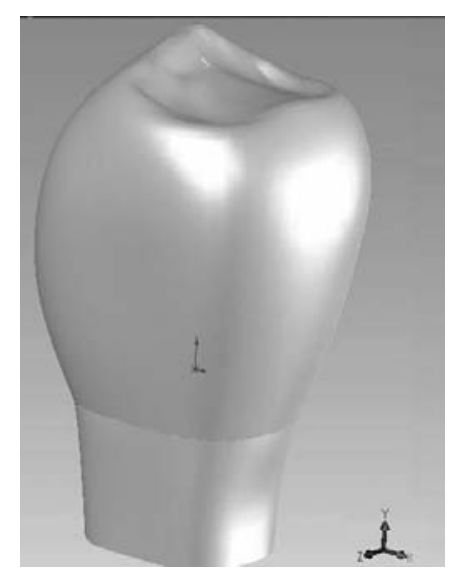

Figure 3. Final 3D model of an intact tooth with defined boundary conditions

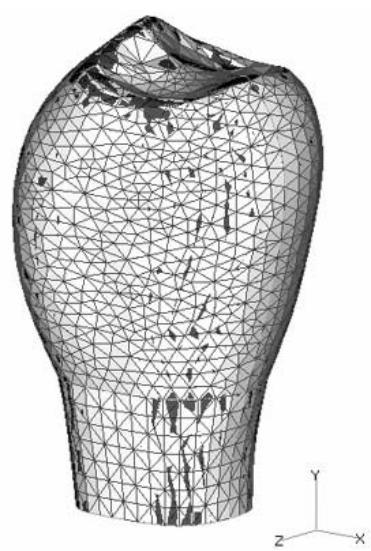

Figure 4. 3D intact tooth model with generated finite element mesh

The next step was to define intensity, direction and location of forces that would be simulated in the study representing the occlusal loads. Because of the variety of occlusal forces values (which differ among individuals, types of food chewing, conditions of occlusion) this study adopted vertical loading with intensity $250 \mathrm{~N}$. Simulated loads over the intact tooth were vertical at right angles to the inner aspects of the cusp slopes, away from the cusp tip. The existence of possible horizontal forces were neglected.

\section{RESULTS}

The results of the study are presented graphically as maps of stress distribution within the investigated model. Total displacement (translation), maximum principal stress $\sigma_{\max }$ and minimum principal stress $\sigma_{\min }$ were evaluated.

Total displacement of the intact tooth after occlusal loading is shown in Figure 5. The greatest displacement values are recorded at the cusp tip, due to tooth structure deformation encountered as a result of loading. 

modeling of specific biological structures

Obviously, great deformations happen in the very place where load is applied and therefore the greatest displacement values are observed there. Moving away from the loading point along the long axis of the tooth in the apical direction the displacement decreases. This is probably the mechanism for occlusal load amortization within the intact tooth structure. Such findings are partly recognised as a consequence of the applied boundary conditions.

The values for $\sigma_{\max }$ and $\sigma_{\min }$ were also found to be highest at the occlusal portion of the tooth. Concentration of stresses was greatest at the location of loading. Stress rapidly decreased in the occluso-gingival direction. Close to the cemento-enamel junction (CEJ) stress again increased and became concentrated at that location. The pattern of stress distribution through the rest of the tooth structure showed reasonably symmetrical distribution with the exception of the occlusal surface and the location close to the CEJ (Figures 6 and 7).
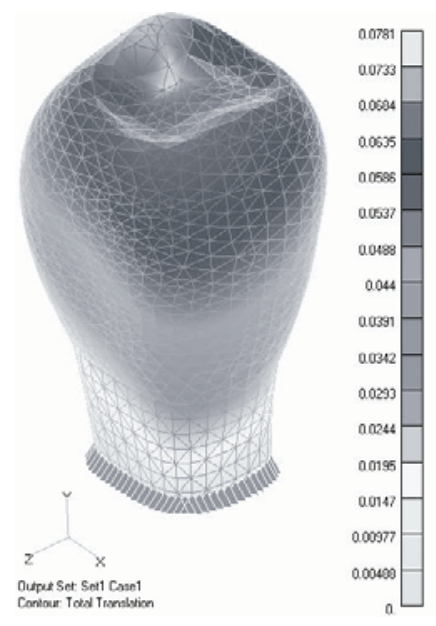

Figure 5. Total displacement (translation) of the intact tooth model
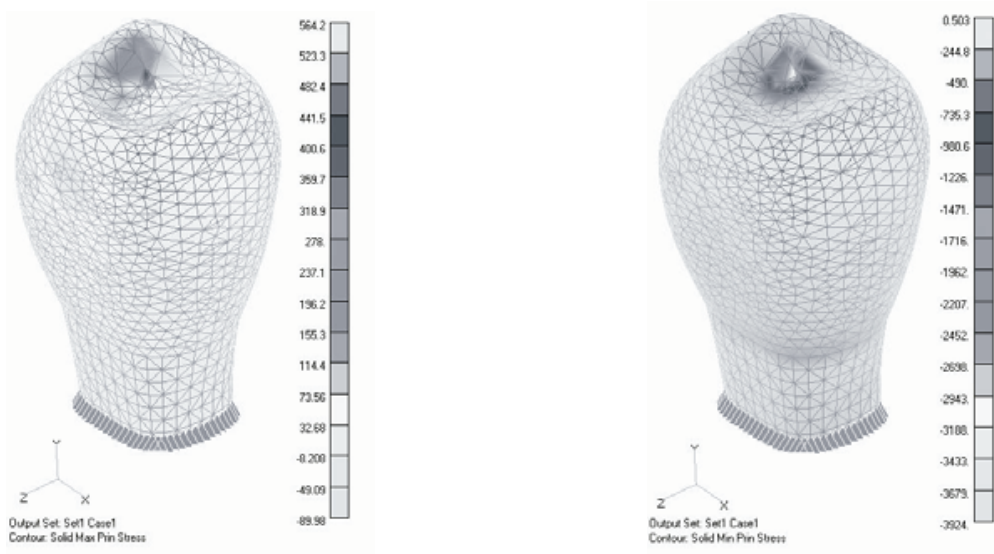

Figure 6. Distribution of maximum principal stress of the intacttooth model
Figure 7. Distribution of minimum principal stress of the intact tooth model 


\section{DISCUSSION}

The modeling presented in this paper, which comprises the dimensions known from literature for creating tooth geometry, involves the problem of having great variations in dimensions of some parameters. However, this approach to modeling enables that mechanical characteristics for each part of the tooth structure can be defined and adequate geometry compatibility between them with continuous non-stop visual control can be reached. Observed errors can be corrected by returning one step backward or returning to the step where planes and cross-sections were determined at the very beginning. Literature data showed that many researchers considered the method for geometry modeling as a useful tool, and used similar methods in their investigations (Lin et al., 2001; Rees, 2002).

The other way to create a tooth model is based on collecting serial images of transversal sections of the tooth (Rubin et al., 1983; Anusavice and Hojjatie, 1988; Goel et al., 1990; Palamara et al., 2000; Lee et al., 2002). This method, where data for geometry modeling are gained from digitizing transversal tooth sections carries the possibility for not making visible errors. The errors are a consequence of sharp edges created due to cutting. Digitizing these errors, they become more evident and therefore have to be corrected before the finite element mesh is formed. Also unavoidably, some sections are deformed or destroyed, thus making more difficult to achieve the exact volume representation of the tooth.

Except for the described methods, with the development of digital imaging techniques even more efficient methods for 3D model creating are now available. These include the application of specialized software for the direct transformation of 2- or 3-dimensional information in image data from computed tomography (CT) or magnetic resonance imaging (MRI) into FEA meshes (Korioth and Versluis, 1997). According to the authors that is a fully automated method of converting segmented data into a volumetric mesh and a very useful tool for medical and biomechanical research, as it significantly reduces the time and effort required to generate patient specific FE and RP models.

Most of the researchers considered materials as elastic, homogeneous and isotropic (de Vree et al., 1984; Williams and Edmunson, 1984; Lin et al., 2001). From the mechanical point of wiew, this claim is true for dentin which is elastic and isotropic, while enamel does not show such characteristics. Enamel is more anisotropic and some authors have modeled enamel as anisotropic (Yettram et al., 1976; Rees and Jacobsen, 1995). Although such enamel modelling was more orthotropic, the principal material axes coincided with the the direction of enamel prisms and were assumed to be perpendicular to the enamel-dentin junction. Following the recommendations of Versluis (1996) and Darendeliler et al. (1998) materials which compose the tooth structure, we modeled as isotropic and homogenous. Especially for reasons that there are still no literature data on dental structure unhomogeneous and anisotropic properties.

The results of the performed analysis, where intact tooth behavior under occlusal loading was investigated, support the findings of previous studies (Khera et al., 1988; Arola et al., 2001; Ausiello et al., 2002; Lemic et al., 2006). A 
characteristic distribution of stress throughout the tooth structure was found, where enamel was not subjected to deformations, but rather transfer of stress forces to resilient dentin below it. As expected the high value of stress happens at the location of the cemento-enamel junction, where enamel is very thin. However, the high stress concentration may be partly recognised as a consequence of definied boundary conditions, where tooth model was constrained $2 \mathrm{~mm}$ below the CEJ.

Finite element analysis is not uknown in veterinary science research, and is gaining popularity among reserchers. Cross et al. 1999, compared the data from experimental and FE studies in order to o determine the validity of finite element analysis as a mean of examining biomechanical properties. The mentioned authors found strong correlations among experimental and FEA data, indicating that FEA is a valid method in veterinary biomechanical research. Distribution of stress and strain in the canine femur during various activities using FEA was evaluated by Shahar et al. (2003). The authors stated that this is an important information for veterinary orthopedic surgeons, engineers designing implants for dogs, and researchers of human orthopedics who use dogs as a model. Hinterhofer et al. (2005) created a computer-based finite element model of the bovine claw with the aim to use FEA to estimate stress and deformation of a physiologically-shaped model claw under static load in order to visualize potential material weakness and to evaluate the effect of different flooring conditions. Maretta et al. (1994) developed a study model of the dolicocephalic dog maxillary and mandibular teeth. The maxillary and mandibular canine teeth, the maxillary fourth premolar tooth, and the mandibular first molar tooth and surrounding bone were harvested from a dog following euthanasia to be used as a teaching and study model. Gioso et al. (2004) reported the procedures for the construction of dental study models, but to create a tooth model according to the descried procedures is even more useful. Once when a mathematical model is made, by changing the parameters it is possible to investigate different clinical situations.

\section{CONCLUSION}

FEM is an effective tool that has been adapted from the engineering arena to biomechanic research. The results of biomechanic research on computational models of biological structures are usefull, because they enable us to locate the weak points in the material or in the design of any structure after loading. When making conclusions one always has to keep in mind the assumptions that are normally involved in FEM analysis, and are usually part of the model creating process. Sometimes due to inaccurate geometrical and material approximations some results could be an overstatement, but anyway would provide the information about mechanism failure. Also, it must be emphasized that FEM as a scientific tool will contributes to the growing scientific basis of knowledge in veterinary dentistry. 
Address for correspondence:

Tihaček Šojić Ljiljana

School of Dentistry,

University of Belgrade

Rankeova 4,

11000 Belgrade, Serbia

\section{REFERENCES}

1. Anusavice KJ, Hojjatie B, 1987, Stress Distribution in Metal-Ceramic Crowns with a Facial Porcelain Margin, J Dent Res, 66, 9, 1493-8.

2. Anusavice KJ, Hojjatie B, 1988, Influence of incisal length of ceramic and loading orientation on stress distribution in ceramic crowns, J Dent Res, 67, 1371-5.

3. Arola D, Galles LA, Sarubin MF, 2001, A comparasion of the mechanical behavior of posterior teeth with amalgam and composite MOD restorations, $J$ Dent, 29, 63-73.

4. Ash MM, Nelson SJ, 2003, Wheeler's Dental Anatomy, Physiology and Occlusion, Eighth edition Elsevier Science, 230-8.

5. Ausiello P, Apicella A, Davidson CL, 2002, Effect of adhesive layer properties on stress distribution in composit restorations - a 3D finite element analysis, Dent Mater, 18, 295-303

6. Biomaterials Properties Database, 1996, University of Michigan Quintessence Publishing, http://www.lib.umich.edu/libhome/Dentistry.lib/Dental tables.html

7. Cross AR, Aron DN, Budsberg SC, Foutz TL, Pearman BT, Evans MD, 1999, Validation of a finite element model of the Kirschner-Ehmer external skeletal fixation system, Am J Vet Res, May, 60, 5, 615-20.

8. Darendeliler SY, Alacam T, Yaman Y, 1998, Analysis of stress distribution in a maxillary central incisor subjected to various post and core aplications, $J$ End, 24, 107-11.

9. Dejak B, Mlotkowski A, Romanowicz M, 2003. Finite element analysis of stresses in molars during clenching and mastication, J Prosthet Dent, 90, 591-7.

10. de Vree JHP, Peters MCRB, Plasschaert AJM, 1984, The influence of Modification of Cavity Design on Distribution of Stresses in a Restored Molar, J Dent Res, 63,10, 1217-20.

11. Goel VK, Khera SC, Singh K, 1990. Clinical implications of the response of enamel and dentin to masticatory loads, J Prosthet Dent, 64, 446-54.

12. Gioso MA, Carvalho VG, Carvalho PE, 2004, Construction of dental study models, J Vet Dent, June, 21, 2,122-6.

13. Hinterhofer C, Ferguson JC, Apprich WV, Haider H, Stanek C, 2005, A finite element model of the bovine claw under static load for evaluation of different flooring conditions, $N Z$ Vet J, June, 53, 3, $165-70$.

14. Khera SC, Goel VK, Chen RCS, Gurusami SA, 1988, A three-dimensional finite element model, Oper Dent, 13, 128-37

15. Korioth TWP, Versluis A, 1997, Modeling the mechanical behavior of the jaws and their related structures by finite element (FE) analysis, Crit Rev Oral Biol Med, 8,1, 90-104

16. Lee HE, Lin CL, Wang CH, Cheng CH, Chang CH, 2002, Stresses at the cervical lesion of maxillary premolar - a finite element investigation, J Dent, 30, 283-90.

17. Lemić AM, Tihaček Šojić LJ, Ilić J, Živković R, 2006, Computational modeling of specific biological structures behavior, Acta Veterinaria (Beograd), 56, 4, 367-74.

18. Lin CL, Chang $C H$, Wang $C H$, Ko CC, Lee $H E$, 2001, Numerical investigation of the factors affecting interfacial stresses in an MOD restored tooth by auto-meshed finite element method, $J$ Oral Rehabil, 28, 517-25.

19. Lin CL, Lin CL, Chang CH, Wang CH, Ko CC, 2001, Multifactorial analyis of an MOD restored human premolar using auto-mesh finite element approach, J Oral Rehabil, 28, 576-85.

20. Maretta SS, Eurell JA, Klippert L, 1994, Development of a teaching model for surgical endodontic access sites in the dog, $J$ Vet Dent, Oct,11, 3, 89-93 
21. Palamara D, Palamara JEA, Tyas MJ, Messer HH, 2000. Strain patterns in cervical e namel of teeth subjected to occlusal loading, Dent Mat, 16, 412-9.

22. Rees JS, Jacobsen PH, 1995, Modelling the effects of enamel anisotropy with the finite element method, J Oral Rehabil, 22, 451-4.

23. Rees JS, 2002, The effect of variation in occlusal loading on the development of abfraction lesions: a finite element study, J Oral Rehabil, 29, 188-93.

24. Rubin C, Krishnamurthy N, Capilouto E, Yi H, 1983, Stress Analysis of the human tooth using a three-dimensional finite element model, J Dent Res, 62, 2, 82-6.

25. Schillinburg HT, Jacobi R, Brackett SE, 1991, Fundamentals of Tooth Preparations. Second printing Quintessence Publishing Co. 13-5.

26. Shahar R, Banks-Sills L, Eliasy $R, 2003$, Stress and strain distribution in the intact canine femur: finite element analysis, Med Eng Phys June, 25, 5, 387-95.

27. Tanaka M, Naito T, Yokota M, Kohno M, 2003, Finite element analysis of the possible mechanism of cervical lesion formation by occlusal force, J Oral Rehabil, 2003, 30, 60-7.

28. Versluis $A, 1996$, Does an incremental filling technique reduce polymerisation shrinkage stresses? J Det Res, 75, 871-8.

29. Williams KR, Edmunson JT, 1984, A finite element stress analysis of an endodontically restored tooth, Engineer Med, 13, 167-73.

30. Yettram AL, Wright KWJ, Pickard HM, 1976. Finite element stress analysis of the crowns of normal and restored teeth, J Dent Res 55, 6,1004-11.

31. Zhou Shu-Min, Hu Hai-Ping, Wang You-Fu, 1989, Analysis of stresses and breaking loads for Class I cavity preparations in mandibular first molars, Quintessence Int, 20, 205-10.

\title{
ANATOMSKO 3D MODELIRANJE SPECIFIČNIH BIOLOŠKIH STRUKTURA
}

\author{
TIHAČEK-ŠOJIĆ LJILJANA, MILIĆ ALEKSANDRA, ŽIVKOVIĆ R i ILIĆ J
}

\section{SADRŽAJ}

Mehaničko ponašanje bioloških struktura je vrlo čest predmet naučnih istraživanja. Rezultati takvih istraživanja pružaju precizne podatke o biomehaničkim karakteristikama bioloških struktura i kao takvi su korisni za predviđanje ponašanja struktura kada su izložene opterećenjima. lako su za sprovođenje takvih istraživanja često korišćene ekesperimentalne životinje, u novije vreme sve su češća takva istraživanja na matematičkim modelima. Pri tome primat ima metoda konačnih elemenata. Da bi se sprovelo istraživanje metodom konačnih elemenata potrebno je napraviti digitalni model strukture koja je predmet istraživanja. Jednom napravljen matematički digitalni model omogućuje primenom računara beskonačan broj promena obika pojedinih elemenata i struktura, ali takođe i bezbroj simulacija aplikacija sila. Cilj ovog rada bio je prikazati način dobijanja trodimezionalnog modela zuba potrebnog za sprovođenje analiza ponašanja zuba nakon okluzalnog opterećenja metodom konačnih elemenata kao i proceniti mogućnost primene ove metode u biomehaničkim istraživanjima u veterinarskoj nauci. Na osnovu podataka iz literature, analizom morfologije ekstrahovanih zuba i plastičnih zuba u odgovarajućim kompjuterskim programima izvršeno je kreiranje 
sopstvenog modela intaktnog zuba. Posebno treba istaći da je MKE vrlo efikasan istraživački alat koji je preuzet iz inžinjerskih oblasti i ima potencijala za širu primenu u veterinarskoj nauci, posebno stomatologiji. 